\title{
IMPLEMENTASI METODE DIROSA DALAM PEMBELAJARAN AL- QUR'AN DEWAN PIMPINAN DAERAH WAHDAH ISLAMIYAH MAKASSAR
}

\author{
Muhammad Saddang \\ Achmad Abubakar \\ Munir
}

Pascasarjana Universitas Islam Negeri Alauddin (UIN) Makassar Email: muhammad.saddang@gmail.com,achmad.abubakar@uin-alauddin.ac.id

\begin{abstract}
Abstrak: Artikel ini bertujuan untuk mengetahui pelaksanaan pembelajaran al-Qur'an dengan menggunakan metode Dirosa, untuk menggali kemampuan peserta didik yang telah mengikuti pembelajaran al-Qur'an dengan menggunakan Metode Dirosa yang dilaksanakan oleh DPD Wahdah Islamiyah Makassar, dan untuk menemukan kendala-kendala yang ada pada implementasi metode Dirosa dalam pembelajaran al-Qur'an DPD Wahdah Islamiyah Makassar berserta solusinya. Penelitian ini tergolong penelitian kualitatif. Penelitian ini menggunakan pendekatan fenomenologis sebagai pendekatan utama dan dibantu dengan pendekatan pedagogis dan psikologis. Hasil penelitian menunjukkan bahwa pembelajaran al-Qur'an dengan menggunakan metode Dirosa dilaksanakan sebanyak 20 kali pertemuan dengan jumlah peserta 10-25 orang per kelompok. Kendala-kendala yang menghambat adalah jadwal pertemuan Dirosa yang sulit ditentukan, kurangnya kedisiplinan peserta, kurangnya waktu dalam mengulangi pelajaran, kendala tempat, dan kendala internal DPD Wahdah Islamiyah Makassar. Adapun solusi dalam mengatasi kendala-kendala tersebut adalah musyawarah antar peserta, memberi motivasi dan semangat kepada peserta didik, komunikasi dengan pengurus masjid, dan melakukan sosialisasi dan perekrutan pengajar Dirosa. Dengan demikian, pembelajaran al-Qur'an dengan menggunakan metode Dirosa harus lebih ditingkatkan dan dikembangkan oleh DPD Wahdah Islamiyah Makassar agar manfaatnya dirasakan oleh masyarakat yang lebih luas.
\end{abstract}

Keywords: Metode Dirosa; Pembelajaran al-Qur'an; DPD Wahdah Islamiyah Makassar 


\section{PENDAHULUAN}

Al-Qur'an merupakan kitab suci umat Islam yang berfungsi sebagai petunjuk dan sebagai pedoman hidup untuk mencapai ridha Allah dan kebahagiaan dunia akhirat. Al-Qur'an dilihat dari segi sisinya berkaitan dengan dua masalah besar yakni masalah dunia dan masalah akhirat.

Al-Qur'an menjadi atu-satunya kitab samawi yang telah terjaga orisinalitasnya sepanjang sejarah ${ }^{1}$. Al-Qur'an telah melalui jalan panjang sejarah dan selalu sesuai dengan tempat dan zaman. Ketika membacanya, memahami ilmu tajwid dan maknanya maka akan terasa kesenangan pada setiap orang yang beriman dan bertakwa karena dengan itu manusia akan mendapatkan petunjuk dari al-Qur'an, tanpa keraguan dikagumi oleh orang-orang yang bertakwa. ${ }^{2}$

Al-Qur'an adalah mukjizat yang abadi, yang diturunkan kepada rasulullah saw., sebagai hidayah bagi manusia dan berisi tentang penjelasan-penjelasan mengenai petunjuk tersebut serta menjadi pembeda antara yang hak dan yang batil. Al-Qur'an diturunkan oleh Allah swt. dalam bahasa Arab yang sangat tinggi susunan bahasanya dan keindahan balāgah. ${ }^{3}$

Mengingat pentingnya mempelajari al-Qur'an, maka dalam memperkenalkan al-Qur'an itu tidak hanya dari sisi fisik dan sejarah semata, namun yang lebih penting adalah bagaimana mampu membaca dan mampu memahami makna yang terkandung dalam ayat demi ayat dalam al-Qur'an sehingga bisa menjadi pelita hidup. ${ }^{4}$ Maka aspek kemampuan baca al-Qur'an merupakan hal pokok yang semestinya diketahui sebagai muslim. ${ }^{5}$

Ilmu tajwid bertujuan untuk memberikan tuntunan bagaimana cara pengucapan ayat dengan tepat, sehingga lafal dan maknanya terpelihara. Pengetahuan tentang makhraj huruf memberikan tuntunan bagaimana cara mengeluarkan huruf dari mulut dengan benar. Pengetahuan tentang sifat huruf berguna dalam pengucapan huruf. Jadi pada intinya tajwid ini digunakan untuk memperbaiki kualitas membaca al-Qur'an.

Namun ada kesenjangan yang besar antara pentingnya membaca al-Qur'an dengan kemampuan membaca al-Qur'an masyarakat muslim di Indonesia. Rektor Perguruan Tinggi Ilmu al-Qur'an (PTIQ) Jakarta, Nazaruddin Umar menilai masyarakat yang buta aksara al-Qur'an masih tinggi di Indonesia. Data Badan

\footnotetext{
${ }^{1}$ Subḥi al-Sāliḥ, Mabāhis Fì Ulūm al-Qur'ān, Terj. Tim Pustaka Firdaus, Membahas IlmuIlmu al-Quran (Cet IX, Jakarta: Pustaka Firdaus, 2004), h. 3.

${ }^{2}$ M. Hadi Ma'rifat, Sejarah al-Quran (Cet. II; Jakarta: Al Huda, 2007), h. 1.

${ }^{3}$ Sa'dulloh, Metode Praktis Menghafal al-Qur'an (Cet. I; Sumedang: Ponpes alHikamussalafi Sukamantri, 2005), h. 34.

${ }^{4}$ Zulfisun Muharram, Belajar Mudah Membaca al-Qur'an dengan Metode Mandiri (Cet. I; Jakarta: Ciputat Press, 2003), h. 1.

${ }^{5}$ Zulfisun Muharram, Belajar Mudah Membaca al-Qur'an dengan Metode Mandiri, h. 2.
} 
Pusat Statistik (BPS) tahun 2015 menyebutkan ada sekitar 54 persen dari total populasi umat Islam di Indonesia yang tidak bisa membaca al-Qur'an. ${ }^{6}$

Pada tahun 2018 masyarakat muslim buta aksara al-Qur'an di Indonesia mengalami peningkatan. Berdasarkan riset Institut Ilmu al-Qur'an bahwa sekitar

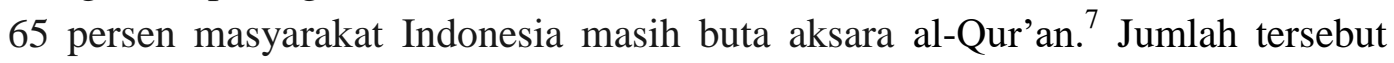
tentu sangat memprihatinkan dan menyedihkan mengingat Indonesia merupakan negara Islam terbesar di dunia dimana al-Qur'an menjadi sumber yang paling utama dalam mempelajari dan memahami Islam.

Fenomena yang terjadi di masyarakat terutama di rumah-rumah keluarga muslim semakin sepi dari bacaan ayat-ayat suci al-Qur'an. Hal ini disebabkan karena terdesak dengan munculnya berbagai produk sain dan tehnologi serta derasnya arus budaya asing yang semakin menggeser minat untuk belajar membaca al-Qur'an sehingga banyak anggota keluarga tidak bisa membaca alQur'an. Akhirnya kebiasaan membaca al-Qur'an ini sudah mulai langka. Yang ada adalah suara-suara radio, TV, Tape recorder, karaoke, dan lain-lain.

Keadaan seperti ini adalah keadaan yang sangat memprihatinkan sebagaimana yang dirasakan pula Komari dan Sunarsih. Pada tahun 1991, pasangan suami istri ini telah memulai gerakan belajar membaca al-Qur'an di tingkat usia kanak-kanak dan usai dewasa. Seiring perjalanan waktu gerakan belajar membaca al-Qur'an semakin berkembang hingga pada tahun 2006 dibuatlah sebuah metode baru dalam mempelajari al-Qur'an yang dikenal dengan Metode Dirosa dan disertai buku panduan.

Buku panduan metode dirosa lahir dari sebuah proses panjang, dari sebuah perjalanan pengajaran al-Qur'an di kalangan ibu-ibu yang dialami sendiri oleh pencetus dan penulis buku tersebut. Telah terjadi proses pencarian format yang terbaik pada pengajaran al-Qur'an di kalangan ibu-ibu selama kurang lebih 15 tahun dengan berganti-ganti metode. Dan akhirnya ditemukanlah satu format yang sementara dianggap paling ideal, paling baik dan efektif, yaitu memadukan pembelajaran baca al-Qur'an dengan pengenalan dasar-dasar keislaman sehingga menjadikan Metode ini sebagai salah satu metode dakwah yang efektif. Metode Dirosa mulai berkembang di daerah Sulawesi, Kalimantan, dan Maluku, yang dibawa oleh para da'i. ${ }^{8}$

${ }^{6}$ Ilham Safutra, "54 Persen Muslim Indonesia Buta Aksara Al-Qur’an”, Jawapos.com. 07 Januari 2016. https://www.jawapos.com/read/2016/06/07/32703/54-persen-muslim-indonesiabuta-aksara-alquran (21 Februari 2018).

${ }^{7}$ Muhyiddin, "Buta Aksara Alquran Masih Tinggi”, Republika.co.id. 09 January 2018. http://khazanah.republika.co.id/berita/dunia-islam/islam-nusantara/18/01/09/p2a36z335-butaaksara-alquran-masih-tinggi (21 Februari 2018).

${ }^{8}$ Komari dan Sunarsih, Panduan Pengelolaan dan Pengajaran Dirosa (Cet. III; Bogor: Yayasan Cita Mulia Mutiara, 2015), h. 7. 
Metode Dirosa ini selanjutnya menjadi program nasional Wahdah Islamiyah pada tahun 2009 dan Dewan Pimpinan Daerah Wahdah Islamiyah Makasssar menjadi salah satu daerah binaan Wahdah Islamiyah yang aktif melakukan pembinaan dalam pembelajaran al-Qur'an dengan menggunakan Metode Dirosa dan secara khusus dilaksanakan sebagai salah satu program kerja salah satu departemen yaitu Lembaga Pembinaan dan Pengembangan Pengajaran al-Qur'an Wahdah Islamiyah Makassar.

Dalam mengembangkan metode Dirosa, Lembaga Pembinaan dan Pengembangan Pendidikan al-Qur'an Dewan Pimpinan Daerah Wahdah Islamiyah Makassar menggelar pelatihan dan rekruitmen pengajar Dirosa pada 1 Juni 2014. Kegiatan tersebut yang berlangsung di Masjid Darul Hikmah, Kegiatan ini diikuti sebanyak 27 calon pengajar dan diharapkan nanti para pangajar tersebut ikut serta dalam pembelajaran al-Quran dengan menggunakan Metode Dirosa. ${ }^{9}$

Dari uraian di atas, cukup penting untuk diformulasikan permasalahan yang menjadi fokus dari tulisan ini sebagai berikut:

1. Bagaimana pelaksanaan Metode Dirosa DPD Wahdah Islamiyah Makassar?

2. Bagaimana kemampuan peserta Metode Dirosa DPD Wahdah Islamiyah Makassar?

3. Bagaimana kendala Metode Dirosa DPD Wahdah Islamiyah Makassar?

\section{KAJIAN TEORETIS}

\section{A. Pengertian Membaca al-Qur'an}

Membaca al-Qur'an adalah melafalkan huruf-huruf menjadi kata dan kalimat dengan pengucapan yang jelas berbeda huruf demi huruf dalam satu kalimat atau satu ayat. Membaca al-Quran menjadi sebuah kewajiban bagi setiap orang muslim. Karena membaca al-Quran merupakan pintu awal dalam memahami, merenungkan hingga mengamalkan isinya sebagai pedoman hidup. Bahkan kita dianjurkan untuk menghafalkan al-Quran. ${ }^{10}$

Membaca adalah kunci dasar pembelajaran al-Qur'an. Setiap muslim wajib hukumnya mempelajari dan memahami al-Qur'an. Dalam menunaikan kewajiban tersebut, maka seseorang harus memiliki dua kemampuan yaitu: kemampuan membaca dan menulis ayat-ayat al-Qur'an sehingga hikmah-hikmah yang terkandung dalam al-Qur'an dapat dipahami dan direalisasikan dalam kehidupan sehari-hari. Selanjutnya membaca dapat dipahami sebagai usaha mendapat sesuatu yang ingin diketahui, mempelajari sesuatu yang akan dilakukan,

\footnotetext{
${ }^{9}$ Wahdah Islamiyah, "LP3Q Makassar rekrut pengajar Dirosa", Situs Resmi Wahdah Islamiyah. http://wahdah.or.id/lp3q-wi-makassar-rekrut-pengajar-dirosa/(26 Juli 2018).

${ }^{10}$ Taufik Adnan Amal, Rekonstruksi Sejarah al-Qur'an, (Yogyakarta: Forum Kajian Budaya dan Agama (FKBA), 2001), h. 45.
} 
atau mendapat kesenangan atau pengalaman, atau melihat serta memahami isi dari apa yang tertulis (dengan melisankan atau hanya di hati). ${ }^{11}$

Membaca merupakan salah satu perintah yang berharga diberikan kepada manusia sebab banyak manfaat yang didapatkan dengan membaca untuk kehidupan dunia dan akhirat. Di antaranya adalah membaca merupakan jalan yang mengantarkan manusia mencapai ilmu yang bermanfaat dan jalan untuk mencapai derajat kemanusiaan yang sempurna.

\section{B. Aspek-Aspek Penilaian pada Pembelajaran al-Qur'an}

Aspek-aspek penilaian pada pembelajaran al-Qur'an antara lain sebagai berikut:

1. Ketartilan dalam Membaca al-Qur'an

Tartīl berasal dari kata rattala, yang berarti membaca dengan bagus dan melagukan. ${ }^{12}$ yang pada awal Islam hanya bermakna pembacaan al-Qur'an secara metodik, dengan cakupan pemahaman tata cara berhenti (waqaf) dan meneruskan (wașal). Namun dalam perkembangan selanjutnya, istilah tersebut bukan lagi untuk merujuk pembacaan al-Qur'an tetapi merujuk kepada pembacaan secara cermat dan perlahan-lahan.

Tartīl dalam membaca al-Qur'an yaitu dengan membaca al-Qur'an dengan tenang dan tadabbur, dengan kecepatan standar sehingga pembaca bisa maksimal memenuhi setiap hukum bacaan dan sifat-sifat huruf yang digariskan. ${ }^{13}$

Tartīil merupakan hadirnya hati ketika membaca al-Qur'an, tidak hanya menyebutkan setiap huruf dari tenggorokan dengan irama lantunan sebagaimana yang dilakukan oleh para Qāri'. Hikmah tartīl yang sesungguhnya adalah memungkinkan perenungan pada hakikat-hakikat ayat dan detail-detailnya. ${ }^{14}$

2. Kefasihan dalam Membaca al-Qur'an

Kefasihan membaca al-Qur'an selain ditentukan oleh penguasaan terhadap ilmu tajwid, juga ditentukan oleh kemampuan lidah seseorang dalam melafalkan huruf dan kalimat-kalimat Arab (al-Qur'an) sesuai dengan ciri, sifat, karakter, dan makhraj hurufnya masing-masing. Dengan demikian membaca al-Qur'an dengan fasih yaitu harus menerapkan kaidah makhraj dan sifatnya.

3. Ketepatan Tajwid

Untuk meningkatkan kemampuan dalam membaca al-Qur'an dengan baik maka harus disertai dengan kaidah-kaidah dalam membaca al-Qur'an yang disebut dengan tajwid. Tajwid adalah memperbaiki bacaan al-Qur'an dalam bentuk

\footnotetext{
${ }^{11}$ Tim Penyusun Kamus Pusat Bahasa, Kamus Besar Bahasa Indonesia, h. 72.

${ }^{12}$ Mahmud Yunus, Kamus Arab-Indonesia (Jakarta: Yayasan Penerjemah/Penafsir alQur'an, 1973), h. 137.

${ }^{13}$ Madyan dan Ahmad Shams, Peta Pembelajaran al-Qur'an (Yogyakarta: Pustaka Pelajar, 2008), h. 109.

${ }^{14}$ Ahmad Musțafa al-Marāgi, Tafsìr al-Marāgi , Juz 29 (Semarang: CV Toha Putra, 1993), h. 191.
} 
mengeluarkan huruf-huruf dari makhrajnya dengan memberikan sifat-sifat yang dimilikinya, baik yang asli maupun yang datang kemudian. ${ }^{15}$

\section{Metode Dirosa}

Dalam kamus besar bahasa Indonesia, metode berasal dari Bahasa Yunani methodos yang berarti cara atau jalan yang ditempuh. Sehubungan dengan upaya ilmiah, maka, metode menyangkut masalah cara kerja untuk dapat memahami objek yang menjadi sasaran ilmu yang bersangkutan. Fungsi metode berarti sebagai alat untuk mencapai tujuan, atau bagaimana cara melakukan atau membuat sesuatu. ${ }^{16}$

Dan dalam Bahasa Arab, metode disebut minhāj, wasīlah, kaifiyah, dan thariquh. Semuanya adalah sinonim, namun yang paling populer digunakan dalam dunia pendidikan Islam adalah tharīqah, bentuk jama' dari thurūq yang berarti jalan atau cara yang harus ditempuh. ${ }^{17}$ Dengan demikian metode adalah cara teratur yang digunakan untuk melaksanakan suatu pekerjaan agar tercapai sesuai dengan yang dikehendaki atau cara kerja yang bersistem untuk memudahkan pelaksanaan suatu kegiatan guna mencapai tujuan yang ditentukan. Sedangkan Dirosa merupakan singkatan dari Pendidikan al-Qur'an orang dewasa. ${ }^{18}$

Metode Dirosa adalah pola pembinaan al-Qur'an dan dasar-dasar keislaman yang dikelola secara sistematis, berjenjang dan berlangsung terusmenerus. ${ }^{19}$ Metode Dirosa merupakan sistem pembinaan Islam berkelanjutan, diawali dengan belajar baca al-Qur'an.

Secara garis besar metode pengajaran al-Qur'an metode Dirosa adalah Baca-Tunjuk-Simak-Ulang, yaitu pembina membacakan, peserta menunjuk tulisan, mendengarkan dengan seksama kemudian mengulangi bacaan tadi. Teknik ini dilakukan bukan hanya bagi bacaan pembina, tetapi juga bacaan dari sesama peserta. Semakin banyak mendengar dan mengulang, semakin besar kemungkinan untuk bisa baca al-Qur'an lebih cepat.Metode Dirosa ini diharapkan menjadi pola pembinaan alternatif yang efektif di kalangan orang dewasa, baik untuk ibu-ibu maupun bapak-bapak yang dikelola secara berkesinambungan dan berjenjang. $^{20}$

\footnotetext{
${ }^{15}$ Ahmad Syarifuddin, Mendidik Anak Membaca, Menulis, dan Mencintai al-Qur'an (Bandung: PT. Remaja Rosdakarya, 2008), h. 91.

${ }^{16}$ Tim Penyusun Kamus, Kamus Besar Indonesia, (Cet. empat, Jakarta, Balai Pustaka, 2007). h. 741.

${ }^{17}$ Abu Tauhied, Beberapa Aspek Pendidikan Islam, (Yogyakarat, Fak.Tarbiyah IAIN Sunan Kali Jaga, 1990). h. 72.

${ }^{18}$ Komari dan Sunarsih, Dirosa (Cet. XXXXIV; Bogor: Yayasan Citra Mulia Mutiara, 2017), h. 3 .

${ }^{19}$ Wahdah Islamiyah, "Belajar Membaca Alquran Dari Nol Dengan Metode Dirosa", Situs Resmi Wahdah Islamiyah. http://wahdah.or.id/belajar-membaca-alquran-dari-nol-dengan-metodedirosa/(7 Maret 2018).

${ }^{20}$ Komari dan Sunarsih, Dirosa, h. 6.
} 
Metode Dirosa ditemukan oleh pasangan suami istri yaitu Komari dan Sunarsih. Komari lahir di Kediri pada tanggal 5 Mei 1968. Saat ini Komari menjadi salah satu pengurus pusat DPP Wahdah Islamiyah yang diamanahkan sebagai Ketua LP3Q DPP Wahdah Islamiyah. Selain itu Komari juga sebagai salah satu guru Matematika di SMP Negeri 24 Makassar. Sunarsih lahir di Sragen pada tanggal 26 April 1966 dan menjadi salah satu alumni Universitas Islam Negeri Alauddin pada tahun 1992 yang pada saat itu masih bernama IAIN Alauddin Makassar. Selain ibu rumah tangga, Sunarsih juga aktif sebagai Kepala TK-TPA Nurul Istiqomah di Kabupaten Gowa. ${ }^{21}$

Selain metode Dirosa, Komari dan Sunarsih juga memiliki beberapa karya lain yaitu Materi Hafalan Santri, Akidah Islam, Ibadah Praktis, Akhlak Anak Islam, dan Sirah Nabawi. Pasangan suami istri ini tinggal di Jalan Pallangga Raya 150 Pangkabinanga, Kecamatan Pallangga, Kabupaten Gowa. ${ }^{22}$

Tujuan yang diharapkan dengan adanya Metode Dirosa adalah sebagai berikut:

1. Memberikan pembinaan baca Al- Qur'an kepada remaja dan orang dewasa dengan baik, lancar dan benar sesuai dengan kaidah ilmu tajwid.

2. Memberikan pengajaran dasar-dasar ilmu keislaman. ${ }^{23}$

Adapun panduan singkat metode Dirosa yang digunakan dalam pembelajaran al-Qur'an adalah sebagai berikut:

1. Tiap kelas terdiri dari 10-25 orang peserta.

2. Disiapkan papan tulis dan alat tulis, tiap peserta memegang buku Dirosa, alat tunjuk.

3. Posisi duduknya menghadap ke depan (menghadap papan tulis).

4. Pengajarannya selama 90 menit setiap pertemuan. ${ }^{24}$

Peserta yang mengikuti pembelajaran al-Qur'an metode Dirosa di DPD Wahdah Islamiyah Makassar disampaikan dan dipahamkan sejak awal setelah pertemuan 20 dan munaqasyah seluruh peserta didik yang lulus dalam ujian munaqasyah akan melanjutkan pembelajaran al-Qur'an pada kelompok tahsīn alqirāah. Sedangkan peserta yang tidak lulus harus mengulang.

${ }^{21}$ Komari (50 tahun), Ketua LP3Q DPP Wahdah Islamiyah Makassar, Wawancara, Makassar, 7 Agust us 2018.

${ }^{22}$ Komari (50 tahun), Ketua LP3Q DPP Wahdah Islamiyah Makassar, Wawancara, Makassar, 7 Agust us 2018.

${ }^{23}$ Wahdah Islamiyah, "Belajar Membaca Alquran Dari Nol Dengan Metode Dirosa", Situs Resmi Wahdah Islamiyah. http://wahdah.or.id/belajar-membaca-alquran-dari-nol-dengan-metodedirosa/(27 Juli 2018).

${ }^{24}$ Komari dan Sunarsih, Dirosa (Cet. XXXXIV; Bogor: Yayasan Citra Mulia Mutiara, 2017), h. 8. 


\section{METODE PENELITIAN}

Penelitian ini tergolong penelitian kualitatif. Penelitian ini menggunakan pendekatan fenomenologis sebagai pendekatan utama dan dibantu dengan pendekatan pedagogis dan psikologis. Sumber data dalam penelitian ini adalah para pengajar metode Dirosa DPD Wahdah Islamiyah Makassar dan peserta didik sebagai sumber data primer dan dokumen-dokumen sebagai sumber data sekunder. Peneliti mengumpulkan data dengan melakukan observasi, wawancara, dan dokumentasi. Data tersebut diolah dan dianalisis melalui tiga tahap, yaitu kondensasi data, penyajian data, dan penarikan kesimpulan. Data tersebut diuji keabsahannya dengan perpanjangan pengamatan, meningkatkan ketekunan, dan triangulasi.

\section{HASIL PENELITIAN DAN PEMBAHASAN}

\section{A. Pelaksanaan Pembelajaran Al-Qur'an dengan Menggunakan Metode} Dirosa

Proses pembelajaran al-Qur'an dengan menggunakan Metode Dirosa DPD Wahdah Islamiyah Makassar dijalankan sesuai dengan arahan dan bimbingan dari Lembaga Pembinaan dan Pengembangan Pendidikan al-Qur'an (LP3Q) DPP Wahdah Islamiyah yang memang membawahi seluruh LP3Q DPD Wahdah Islamiyah se Indonesia dan bertanggungjawab atas pelaksanaan pembelajaran alQur'an dengan Metode Dirosa di seluruh DPD Wahdah Islamiyah di Indonesia termasuk DPD Wahdah Islamiyah Makassar.

Lembaga Pembinaan dan Pengembangan Pendidikan al-Qur'an DPP Wahdah Islamiyah telah menyediakan dua buku dalam menunjang proses pembelajaran al-Qur'an dengan menggunakan Metode Dirosa yaitu buku yang berjudul "Dirosa" yang berisi tentang panduan singkat dan isi materi yang diajarkan dalam Metode Dirosa dan buku yang lainnya berjudul "Panduan Pengelolaan dan Pengajaran Dirosa" yang menjadi pedoman para pengajar Dirosa dalam mengajarkan al-Qur'an dengan metode Dirosa.

Tujuan utama dari program Dirosa adalah memberikan pembinaan dalam membaca al-Qur'an kepada remaja dan orang dewasa dengan baik, lancar dan benar sesuai dengan kaidah ilmu tajwid dan memberikan pengajaran dasar-dasar ilmu keislaman.

\section{Petunjuk Umum Metode Dirosa}

Dalam melaksanakan program Dirosa, DPD Wahdah Islamiyah Makassar membatasi jumlah peserta Dirosa yaitu minimal 10 orang dan maksimal 25 orang. Berdasarkan hasil observasi ditemukan bahwa di antara kelompok binaan Dirosa ada yang berjumlah 15 orang. Selain itu adapula kelompok binaan yang berjumlah 10 orang, 13 orang, dan 20 orang.

Setiap peserta Dirosa juga memiliki buku Dirosa masing-masing yang digunakan dalam pembelajaran. Selain itu dengan buku Dirosa setiap peserta 
akan mudah mengulangi pelajaran di luar pertemuan Dirosa seperti di rumah dan di tempat yang lain. Selain itu juga disiapkan papan tulis dan alat tulis dalam menunjang pembelajaran.

Berdasarkan hasil observasi didapatkan bahwa pertemuan Dirosa dilaksanakan malam hari. Pertemuan Dirosa dilaksanakan dua kali sepekan yaitu malam selasa dan malam jumat dan dimulai setelah shalat isya sampai pukul 20.00 Wita. Pertemuan tersebut berlangsung sekitar dua jam. 90 menit digunakan untuk pembelajaran Dirosa dan selebihnya digunakan untuk tanya jawab, makan bersama, dan problem solving.

Dalam pembelajaran al-Qur'an dengan menggunakan Metode Dirosa yang dilaksanakan oleh DPD Wahdah Islamiyah Makassar pengajar berusaha menciptakan suasana nyaman dalam belajar. Selain itu pengajar juga berusaha menciptakan kedekatan dengan para peserta di awal pembelajaran agar tercipta suasana kekeluargaan dan ketenangan dalam belajar.

Pendekatan yang digunakan pengajar Dirosa dengan membangun komunikasi yang baik dengan menanyakan kabar dan kondisi kesehatan peserta dan peserta juga diberi kesempatan untuk mengajukan pertanyaan baik tentang bacaan al-Qur'an maupun tentang wawasan keislaman secara umum dan juga tentang pesmasalahan pribadi.

Dengan cara tersebut peserta merasakan kenyamanan dalam belajar dengan tambahan motivasi dan semangat dari pengajar sehingga memudahkan peserta dalam memahami pelajaran dan mengikuti pertemuan Dirosa sampai selesai selama 20 pertemuan serta merasakan adanya perubahan dan peningkatan kemampuan dalam membaca al-Qur'an setelah mengikuti pembelajaran al-Qur'an dengan menggunakan Metode Dirosa yang dilaksanakan oleh DPD Wahdah Islamiyah Makassar.

\section{Teknik Pengajaran Metode Dirosa}

Dalam pembelajaran al-Qur'an dengan Metode Dirosa DPD Wahdah Islamiyah Makassar menggunakan dua jenis metode yaitu metode klasikal dan metode drill. Metode klasikal yaitu metode yang menjadikan peserta lebih aktif dan lebih banyak membaca dan mengulangi pelajaran yang sedang diajarkan melebihi bacaan pengajar. Sedangkan metode drill yaitu peserta harus aktif dalam mendengarkan dengan seksama kemudian menirukan bacaan yang didengarkannya baik dari pengajar atau dari peserta yang lain.

Dalam pembahasan materi yang sedang diajarkan, pengajar Dirosa DPD Wahdah Islamiyah Makassar menulis materi satu per satu di papan tulis atau dengan menggunakan peraga kemudian melafalkannya dan ditirukan oleh peserta

Selain dua metode tersebut, DPD Wahdah Islamiyah Makassar juga menggunakan tiga jenis teknik yaitu Teknik 1, Teknik 2, dan Teknik 3. Teknik 1 disingkat dengan $\mathrm{T} 1$ yang disebut juga dengan Contoh yaitu pengajar 
membacakan materi sedangkan peserta menunjuk tulisan yang sedang dibaca pengajar. Sedangkan Teknik 2 disingkat T2 yang disebut dengan Tuntun yaitu pengajar membacakan materi kemudian peserta menirukan, jika bacaan belum kompak, pengajar mengulangi bacaannya kemudian ditirukan oleh semua peserta.

Adapun Teknik 3 disingkat T3 yang disebut Baca Bersama yaitu pengajar dan semua peserta membaca secara bersama-sama. Selain itu digunakan pula teknik Baca Simak yang disingkat BS yaitu satu per satu dari semua peserta bergiliran membaca satu baris. Ketika dibaca peserta yang lain menirukan. Pengajar menyimak dengan seksama dengan membenarkan yang salah serta menandai bagian yang belum dikuasai peserta.

Pengajar Dirosa DPD Wahdah Islamiyah Makassar juga menggunakan metode membaca berpasangan dan metode membaca mandiri. Membaca berpasangan yaitu dua peserta saling berhadapan lalu satu orang peserta membaca satu halaman sedangkan pasangannya menyimak dan membenarkan jika ada kesalahan. Jika mereka berdua tidak menguasai maka ditanyakan kepada pengajar.

Dalam pembelajaran al-Qur'an dengan Metode Dirosa, Pengajar Dirosa DPD Wahdah Islamiyah Makassar menggunakan irama bacaan yang biasa disebut murattal yang sederhana yaitu angka 1 berarti membaca dengan suara datar, angka 2 membaca dengan suara naik atau suara tinggi, dan angka 3 membaca dengan suara yang menurun.

\section{Materi Inti Dirosa}

Dalam pembelajaran al-Qur'an dengan Metode Dirosa, DPD Wahdah Islamiyah Makassar menggunakan buku Dirosa yang di dalamnya berisi materi yang akan diajarkan. Materi yang ada dalam buku Dirosa tersusun secara sistematis dimulai dari pengenalan huruf sampai pada pengenalan kalimat yang berisi ayat dan potongan ayat yang dalam al-Qur'an.

Materi yang diajarkan dalam program Dirosa DPD Wahdah Islamiyah Makassar secara umum terbagi atas lima bagian yaitu pertemuan 1-4, pertemuan 5, pertemuan 6-8, pertemuan 9 dan 12, dan pertemuan 10-11 dan 13-20.

Pada pertemuan 1-4 materi yang diajarkan adalah seluruh huruf hijaiah satu per satu dengan harakat fathah dan membaca tiga huruf bersambung yang semuanya berharakat fathah. Pertemuan 1-4 terdiri dari dua halaman per pertemuan kecuali pertemua 4 yang terdiri dari 4 halaman. Pada pertemuan pertama dimulai dari huruf hamzah sampai huruf kha, pertemuan kedua dimulai dari huruf dal sampai huruf $d a d$, pertemuan ketiga dimulai dari huruf ta sampai huruf kaf, dan pertemuan ke empat dimulai dari huruf lam sampai ya. Adapun halaman ke tiga dan ke empat pada pertemuan 4 berisi tentang rangkuman dari pertemuan pertama dan mulai diajarkan cara membaca empat huruf yang bersambung. 
Pada pertemuan 5 peserta diajarkan membaca seluruh huruf hijaiah secara berurutan mulai dari hamzah sampai ya dengan harakat fathah kemudian dibaca secara terbalik yaitu dari ya sampai hamzah juga dengan harakat fathah. Selain itu pada halaman kedua peserta diajarkan tentang cara membaca huruf hijaiah tanpa harakat dan juga peserta diajarkan angka dalam bahasa arab mulai dari angka 1 sampai 20.

Pada pertemuan 6-8 peserta diajarkan tentang semua huruf hijaiah dengan 3 harakat yaitu fathah, kasrah, dan dammah. Selain itu diajarkan pula cara membaca tiga huruf bersambung dengan harakat yang berbeda-beda. Pertemuan 6 dimulai dari huruf hamzah sampai sin, pertemuan 7 dimulai dari huruf syin sampai mim, dan pertemuan 8 dimulai dari huruf nun sampai $y a$.

Bagian ke empat dari materi Dirosa adalah pertemuan 9 dan 12. Pada pertemuan 9 peserta diajarkan tentang tanwin dengan bunyi an, in, dan un pada setiap huruf hijaiah mulai dari hamzah sampai ya. Pada halaman kedua peserta diajarkan membaca tiga huruf bersambung yang diakhiri dengan huruf yang berharakat tanwin. Sedangkan pertemuan 12 peserta diajarkan tentang huruf yang memiliki tanda tasydīd dan huruf yang memiliki tanda sukun pada dua huruf yang bersambung. Sedangkan pada halaman kedua peserta diajarkan tentang membaca tiga huruf bersambung yang pada huruf keduanya bertanda tasydìd.

Adapun bagian terakhir dari materi Dirosa yang diajarkan oleh DPD Wahdah Islamiyah Makassar adalah pertemuan 10-11 dan 13-20. Pada pertemuan 10 peserta mulai diajarkan tentang materi tajwid yaitu mad yang terdiri dari mad asli dengan panjang bacaan 2 harakat dan mad wajib dengan panjang bacaan 5 harakat. Pada pertemuan 11 peserta diajarkan tentang Mad Badal dan Mad 'Iwad. Mad yang diajarkan yaitu yang terdiri dari 1 huruf, 2 huruf, 3 huruf, 4 huruf, dan 5 huruf yang bersambung.

Pada pertemuan 13 peserta diajarkan tentang cara membaca sukun pada setiap akhir kata kerja dalam al-Qur'an. Pada pertemua 14 dan 15 peserta diajarkan tentang qalqalah yaitu cara membaca sukun dari huruf ba, jim, dal, ta, dan qaf baik di tengah maupun di akhir kata dalam al-Qur'an. Pada pertemuan 16 peserta diajarkan tentang lam qamariyah, lam syamsiyah, dan gunnah yaitu cara membaca nun dan mim yang memiliki tanda tasydìd. Pada pertemuan 17 berisi tentang potongan ayat dalam al-Qur'an lalu peserta diajarkan tentang cara berhenti di setiap akhir ayat. Setelah itu peserta diajarkan tentang idgām yaitu terdiri atas idgām bigunnah dan idgam bilā gunnah beserta beberapa contohnya yang terdapat dalam ayat-ayat dalam Al-Qur'an. Sadaruddin mengatakan: "Dalam buku Dirosa yang dibaca pada umumnya adalah potongan ayat dalam alQur'an."25

\footnotetext{
${ }^{25}$ Sadaruddin (53 tahun), Peserta Pembelajaran Metode Dirosa DPD Wahdah Islamiyah Makassar, Wawancara, Makassar, 15 Mei 2018.
} 
Pada pertemuan 18 peserta diajarkan tentang iqlāb dan ikhfā syafawi beserta beberapa contohnya yang terdapat dalam ayat-ayat dalam al-Qur'an. Pada pertemuan 19 peserta diajarkan tentang ikhfā dan iz̧har halqi beserta beberapa contohnya yang terdapat dalam ayat-ayat dalam al-Qur'an. Dan pada pertemuan terakhir peserta diajarkan tentang cara membaca cara membaca huruf hijaiah yang terdapat pada beberapa awal surah dalam al-Qur'an, selain itu diajarkan pula cara membaca lafal Allah dalam al-Qur'an yang dibaca tipis dan tebal dan garīb musykilāt serta diakhiri dengan tanda-tanda wakaf dalam al-Qur'an. Umumnya setiap materi akan dibaca oleh peserta sebanyak sembilan kali dengan teknik yang berbeda-beda.

\section{B. Kemampuan Membaca Al-Qur'an Peserta Didik Metode Dirosa}

Setiap peserta didik yang akan mengikuti pembelajaran al-Qur'an dengan Metode Dirosa DPD Wahdah Islamiyah Makassar mempunyai karakter yang berbeda, baik dari segi intelegensi, lingkungan maupun pengalaman sehingga berpengaruh pada kemampuan yang berbeda-beda dalam membaca al-Qur'an. Ilham Idrus Tahir yang merupakan salah satu pengajar Dirosa mengatakan:

Kemampuan bacaan sebelum ikut Dirosa beragam. Ada yang memang tidak tahu sama sekali, ada sudah bisa tapi masih terbata-bata, dan ada yang lancar tapi masih bermasalah di penyebutan huruf. ${ }^{26}$

Berdasarkan wawanvara tersebut, kemampuan peserta sebelum ikut Metode Dirosa secara umum terbagi atas tiga yaitu ada yang sama sekali tidak bisa membaca al-Qur'an atau yang dikenal dengan istilah buta huruf sehingga tidak bisa sama sekali membaca al-Qur'an, ada yang membaca dengan terbatabata, dan ada yang membaca dengan lancar tetapi masih ada kesalahan dalam membaca beberapa huruf yang tidak sesuai dengan makhrajnya.

Adapun secara rinci tentang kemampuan peserta didik sebelum mengikuti pembelajaran al-Qur'an dengan menggunakan metode Dirosa selama 20 kali pertemuan adalah sebagai berikut:

\begin{tabular}{|l|c|}
\hline \multicolumn{1}{|c|}{ Nama } & $\begin{array}{l}\text { Kemampuan Membaca Al-Qur'an } \\
\text { Sebelum Mengikuti Metode Dirosa }\end{array}$ \\
\hline Aris Azis & 15 \\
\hline Edison Latif & 10 \\
\hline Sadaruddin & 16 \\
\hline Herman & 31 \\
\hline
\end{tabular}

${ }^{26}$ Ilham Idrus Tahir (27 tahun), Pengajar Pembelajaran Metode Dirosa DPD Wahdah Islamiyah Makassar, Wawancara, Makassar, 16 Mei 2018. 


\begin{tabular}{|l|c|} 
Muhammad Adhil & 28 \\
\hline Faisal & 30 \\
\hline Muhammad Hamrih & 50 \\
\hline Tri Anugrah Ramadhan Husain & 45 \\
\hline
\end{tabular}

Tabel 4.1. Kemampuan Membaca Al-Qur'an Sebelum Mengikuti Metode Dirosa

Berdasarkan kategori nilai yang ditentukan oleh LP3Q DPD Wahdah Islamiyah Makassar maka kemampuan peserta dapat dirinci sebagai berikut:

a. Kategori buta huruf yaitu Aris Azis, Edison Latif, dan Sadaruddin. ${ }^{27}$

b. Ketegori terbata-bata yaitu Herman, Muhammad Adhil, dan Faisal. ${ }^{28}$

c. Kategori lancar yaitu Muhammad Hamrih dan Tri Anugrah Ramadhan Husain. $^{29}$

Rais yang juga merupakan salah satu pengajar Dirosa DPD Wahdah Islamiyah Makassar juga menjelaskan tentang peserta didik sebelum mengikuti program Dirosa dengan menyatakan:

Sebelum ikut Dirosa kemampuan para peserta bermacam-macam. Ada yang buta huruf sama sekali, ada yang lancar membaca tapi penyebutan huruf masih belum bagus dari sisi makhraj. Ada juga yang lancar membaca tapi hukum-hukum yang berkaitan dengan huruf belum paham, seperti hukum nun sukun dan tanwin, mim sukun, mad, dan bacaan huruf di awal surah. Ada yang tahu huruf tapi tidak lancar membaca alQur'an. ${ }^{30}$

Penerimaan peserta didik yang selama ini dilakukan pada DPD Wahdah Islamiyah Makassar tidak dilakukan secara selektif sehingga menyebabkan peserta didik yang ikut dalam program Dirosa memiliki karakter atau pembawaan yang berbeda-beda. Demikian juga kemampuan membaca al-Qur'an peserta didik program Dirosa DPD Wahdah Islamiyah Makassar berbeda-beda karena pada saat penerimaan peserta didik baru tidak dilakukan pengelompokan berdasarkan kemampuan membaca al-Qur'an.

Sebagian peserta didik ada yang langsung bisa memahami materi karena sebelumnya sudah mempunyai dasar atau bekal pengetahuan membaca al-Qur'an, dan juga peserta didik yang harus dijelaskan berulang-ulang untuk memahami

\footnotetext{
${ }^{27}$ Rais (31 tahun), Pengajar Pembelajaran Metode Dirosa DPD Wahdah Islamiyah Makassar, Wawancara, Makassar, 18 Mei 2018.

${ }^{28}$ Amiruddin (35 tahun), Ketua LP3Q DPD Wahdah Islamiyah Makassar, Wawancara, Makassar, 28 Juli 2018.

${ }^{29}$ Amiruddin (35 tahun), Ketua LP3Q DPD Wahdah Islamiyah Makassar, Wawancara, Makassar, 28 Juli 2018.

${ }^{30}$ Rais (31 tahun), Pengajar Pembelajaran Metode Dirosa DPD Wahdah Islamiyah Makassar, Wawancara, Makassar, 18 Mei 2018.
} 
satu materi Hal inilah yang menjadi tantangan bagi pengajar Dirosa DPD Wahdah Islamiyah Makassar untuk dapat menciptakan interaksi edukatif yang optimal dan pembelajaran Dirosa yang baik. Ketika pengajar Dirosa dihadapkan pada kondisi demikian dan tidak dapat mengelola kelompok Dirosa dengan baik, maka imbasnya adalah proses belajar mengajar pada kelompok Dirosa tersebut tidak berlangsung sebagaimana mestinya.

Setelah melakukan silang informasi dari hasil observasi, wawancara, dan dokumentasi, didapatkan hasil penelitian yang menunjukkan adanya perubahan pada kemampuan peserta didik dalam membaca al-Qur'an setelah mengikuti pembelajaran al-Qur'an dengan menggunakan metode Dirosa selama 20 kali pertemuan yang dilaksanakan oleh DPD Wahdah Islamiyah Makassar dan diakhiri dengan munāqasyah yaitu dengan nilai yang diperoleh sebagai berikut:

\begin{tabular}{|c|c|c|c|}
\hline \multirow[t]{2}{*}{ Nama } & \multicolumn{3}{|c|}{$\begin{array}{c}\text { Kemampuan Membaca Al-Qur'an Setelah } \\
\text { munāqasyah }\end{array}$} \\
\hline & Tartïl & Kefasihan & Tajwid \\
\hline Aris Azis & 93 & 85 & 96 \\
\hline Edison Latif & 90 & 85 & 93 \\
\hline Sadaruddin & 92 & 83 & 95 \\
\hline Herman & 92 & 87 & 94 \\
\hline Muhammad Adhil & 94 & 88 & 95 \\
\hline Faisal & 93 & 86 & 95 \\
\hline Muhammad Hamrih & 95 & 84 & 96 \\
\hline Tri Anugrah Ramadhan Husain & 95 & 83 & 96 \\
\hline
\end{tabular}

Kategori nilai yaitu 80-89 : Baik dan 90-100: sangat baik

Tabel 4.2. Kemampuan Membaca Al-Qur'an Setelah munāqasyah

Berdasarkan tebel 4.2. kemampuan peserta dapat dijelaskan sebagai berikut:

\section{Tartīl}

Peserta didik yang telah mengikuti pembelajaran al-Qur'an dengan menggunakan metode Dirosa selama 20 kali pertemuan telah mampu mengenal huruf hijaiah secara keseluruhan dan mampu mampu membaca al-Qur'an dengan lancar sehingga tidak lagi termasuk dalam kategori buta huruf dan tidak lagi terbata-bata. Dari sisi ini, Metode Dirosa menjadi sarana yang efektif dalam memperbaiki dan meningkatkan kemampuan dalam membaca al-Qur'an. 


\section{Kefasihan}

Peserta didik yang telah mengikuti pembelajaran al-Qur'an dengan menggunakan metode Dirosa selama 20 kali juga telah mampu membaca huruf sesuai dengan makhraj. Meski demikian masih terdapat beberapa huruf yang masih sulit dibaca secara benar sesuai makhraj oleh peserta didik. Huruf-huruf yang dimaksudkan adalah huruf $\underset{d a d}{\mathrm{z}}$ żal, zaa, dan 'ain. Hal ini disebabkan karena peserta belum memahami dengan baik makhraj dari huruf-huruf tersebut dan kurangnya latihan. Oleh karena itu DPD Wahah Islamiyah Makassar membuka kelompok taḥsin atau perbaikan bacaan al-Qur'an setelah ujian munāqasyah sebagai lanjutan dari Metode Dirosa.

\section{Tajwid}

Peserta didik yang telah mengikuti pembelajaran al-Qur'an dengan menggunakan metode Dirosa selama 20 kali pertemuan telah mampu membaca alQur'an sesuai tajwid yang benar. Namun hukum ikhfa' menjadi salah satu hukum tajwid yang belum dikuasai dengan baik oleh peserta didik.

Kemampuan peserta didik dalam membaca al-Qur'an setelah mengikuti Metode Dirosa juga diketahui dari hasil wawancara. Rais yang merupakan salah satu pengajar Dirosa DPD Wahdah Islamiyah Makassar mengatakan:

Metode Dirosa dapat membantu seseorang yang tadinya buta huruf bisa membaca al-Qur'an dengan lancar dan membantu seseorang mempraktekkan hukum-hukum tajwid. Alhamdulillah setelah proses pembelajaran dengan metode ini maka peserta bisa langsung membaca al-Qur'an di dalam surah apapun. ${ }^{31}$

Muhammad Hamrih yang telah mengikuti pembelajaran al-Qur'an dengan menggunakan metode Dirosa selama 20 kali pertemuan yang dilaksanakan oleh DPD Wahdah Islamiyah Makassar dengan mengatakan:

Sebelum mengikuti Metode Dirosa, saya belum bisa membaca al-Qur'an dengan baik. Apalagi mengenali hukum-hukum bacaan bacaan al-Qur'an.

Setelah mengikuti Metode Dirosa saya jadi lebih mengerti mengenai hukum-hukum dalam membaca al-Qur'an. ${ }^{32}$

Berdasarkan wawancara tersebut, para peserta telah merasakan perubahan dan peningkatan dalam membaca al-Qur'an setelah mengikuti pembelajaran alQur'an dengan menggunakan Metode Dirosa.

Hal yang sama juga disampaikan oleh Amiruddin selaku ketua LP3Q DPD Wahdah Islamiyah Makassar dengan mengatakan:

Kemampuan peserta didik setelah ikut dirosa yaitu sudah bisa mengenal dan menyebut huruf hijaiah dengan makhārijul hurūf, ada yang sudah

\footnotetext{
${ }^{31}$ Rais (31 tahun), Pengajar Pembelajaran Metode Dirosa DPD Wahdah Islamiyah Makassar, Wawancara, Makassar, 18 Mei 2018.

${ }^{32}$ Muhammad Hamrih (26 tahun), Peserta Pembelajaran Metode Dirosa DPD Wahdah Islamiyah Makassar, Wawancara, Makassar, 14 Mei 2018.
} 
paham tentang bacaan panjang pendek, dan ada yang sudah membaca alQur'an sesuai kaidah tajwid. ${ }^{33}$

Berdasarkan wawancara tersebut, di antara perubahan yang dialami peserta yang telah mengikuti pembelajaran al-Qur'an dengan menggunakan metode Dirosa selama 20 kali pertemuan yang dilaksanakan oleh DPD Wahdah Islamiyah Makassar adalah kemampuan dalam membedakan bacaan yang panjang dan bacaan yang pendek atau yang dikenal dengan istilah mad dimana mad ini merupakan salah satu kesalahan yang juga banyak dijumpai pada peserta sebelum mengikuti pembelajaran al-Qur'an dengan menggunakan metode Dirosa.

Faisal yang merupakan salah satu peserta yang telah mengikuti pembelajaran al-Qur'an dengan menggunakan metode Dirosa selama 20 kali pertemuan dengan mengatakan:

Sebelum masuk dirosa saya belum bisa membedakan huruf hijaiah, makhraj, dan hukum-hukum tajwid, boleh dibilang saya tidak bisa mengaji sama sekali. Setelah ikut Dirosa Alhamdulillah saya sdh mengetahui huruf Hijaiyah dan penyebutan makhraj sudah hampir sempurna begitu juga hukum tajwid dan Alhamdulillah saya sudah bisa membaca al-Qur'an walaupun belum sepenuhnya sempurna dan saya terus berusaha untuk memperbaiki bacaan saya. ${ }^{34}$

Berdasarkan wawancara tersebut, para peserta yang telah mengikuti pembelajaran al-Qur'an dengan menggunakan metode Dirosa akan tetap dibina oleh DPD Wahdah Islamiyah Makassar agar para peserta tetap rajin membaca alQur'an dan bacaan al-Qur'an para peserta semakin baik dari waktu ke waktu.

\section{Kendala-kendala yang Dihadapi dalam Metode Dirosa dan Solusinya}

\section{Kendala-kendala}

Dalam penerapan pembelajaran al-Qur'an dengan menggunakan metode Dirosa DPD Wahdah Islamiyah Makassar, berbagai kendala senantiasa bermunculan. kendala tersebut merupakan tantangan yang harus dicari jalan keluarnya dengan harapan meminimalisir dan menghilangkan dampak yang ditimbulkannya. Dalam penelitian ini, penulis mengidentifikasi sejumlah kendala yang dihadapi DPD Wahdah Islamiyah Makassar dalam pelaksanaan pembelajaran al-Qur'an dengan menggunakan metode Dirosa. Uraiannya dapat dilihat berikut ini:

a. Jadwal pertemuan Dirosa yang sulit ditentukan

Salah satu kendala dalam penerapan pembelajaran al-Qur'an dengan menggunakan metode Dirosa DPD Wahdah Islamiyah Makassar adalah jadwal pembelajaran yang sulit disesuaikan dengan waktu luang peserta. Hal ini

\footnotetext{
${ }^{33}$ Amiruddin (35 tahun), Ketua LP3Q DPD Wahdah Islamiyah Makassar, Wawancara, Makassar, 15 Mei 2018.

${ }^{34}$ Faisal (35 tahun), Peserta Pembelajaran Metode Dirosa DPD Wahdah Islamiyah Makassar, Wawancara, Makassar, 14 Mei 2018.
} 
disebabkan karena latar belakang peserta yang berbeda-beda terutama dari latar belakang pekerjaan dan kesibukan masing-masing peserta yang berbeda-beda sehingga sulit menyatukan waktu luang.

b. Kurangnya Kedisiplinan Peserta

Peserta yang tidak disiplin dilihat dengan keterlambatan dan ketidakhadiran dalam pertemuan Dirosa sehingga mempengaruhi hasil belajar peserta sebab pertemuan Dirosa dua puluh kali pertemuan sehingga jika satu pertemuan saja ada peserta yang tidak hadir maka akan sangat berpengaruh pada kemampuan peserta dalam membaca al-Qur'an disebabkan akan adanya pelajaran yang tertinggal.

c. Kurangnya waktu dalam mengulangi pelajaran

Pada dasarnya waktu yang digunakan dalam memahami setiap materi dalam satu pertemuan selama 90 menit sudah cukup. Namun yang dianggap kurang adalah waktu dalam mengulangi pelajaran. Hal ini tentu berdampak pada penguasaan materi yang diajarkan. Pengulangan dalam jumlah yang banyak tentu akan menjadikan peserta semakin menguasai meteri yang sedang dipelajari dan kurangnya waktu pengulangan akan menjadikan peserta mudah melupakan meteri yang sedang dipelajari.

d. Kendala Tempat

Di antara kendala yang pernah terjadi pada pembelaran al-Qur'an dengan menggunakan Metode Dirosa adalah tempat. Hal ini disebabkan karena Pembelajaran Dirosa umumnya dilaksanakan di masjid baik masjid binaan DPD Wahdah Islamiyah Makassar maupun masjid umum yang ada di tengah masyarakat Kota Makassar

e. Internal DPD Wahdah Islamiyah Makassar

Namun ada dua hal yang perlu diperhatikan oleh DPD Wahdah Islamiyah Makassar dan secara khusus LP3Q DPD Wahdah Islamiyah Makassar dalam peningkatan pembelajaran al-Qur'an dengan menggunakan metode Dirosa yaitu kurangnya pengajar Dirosa yang dimiliki DPD Wahdah Islamiyah Makassar dan kurang tersosialisaikannya Metode Dirosa ini ke masyarakat Kota Makassar yang lebih luas.

\section{Solusi}

Adapun solusi dalam mengatasi kendala-kendala dalam pembelajaran alQur'an dengan menggunakan metode Dirosa DPD Wahdah Islamiyah Makassar adalah sebagai berikut:

a. Musyawarah antar Peserta

Salah satu kendala dalam pembelajaran al-Qur'an dengan menggunakan metode Dirosa adalah sulitnya menentukan waktu yang cocok bagi setiap peserta dan pengajar. Oleh karena itu dibutuhkan kesepakatan dalam menentukan waktu merupakan solusi yang tepat agar setiap peserta dapat mengusulkan waktu yang 
tepat sesuai kesibukan masing-masing lalu dimusyawarahkan antar peserta tentang jadwal yang paling cocok bagi setiap peserta dan pengajar.

Solusi yang lain yang juga bisa menjadi pilihan dalam masalah penentuan jadwal pertemuan Dirosa ini adalah adanya pemindahan kelompok bagi peserta yang tidak bisa menyesuaikan dengan jadwal yang telah dimusyawarahkan peserta dalam satu kelompok atau mengadakan pembelajaran dengan cara privat.

b. Memberi Motivasi dan Semangat kepada Peserta Didik

Solusi untuk meningkatkan kedisiplinan peserta didik adalah dengan senantiasa memberi motivasi dan semangat tentang pentingnya belajar al-Qur'an. setiap pengajar juga perlu untuk terus mengingatkan peserta tentang keutamaan mempelajari al-Qur'an sebagai salah satu amalan sangat mulia dalam Islam dan ancaman terhadap orang-orang yang mengabaikan al-Qur'an dengan tidak mempelajarinya.

c. Komunikasi dengan Pengurus Masjid

Pembelajaran Dirosa yang paling utama adalah dilaksanakan di masjid. Oleh karena itu izin dari pengurus masjid harus didapatkan sebelum memulai pembelajaran al-Qur'an dengan menggunakan metode Dirosa agar pihak masjid mengetahui kegiatan tersebut sehingga kegiatan tersebut bisa terlaksana dengan aman.

Selain itu pelaksanaan Dirosa bisa juga dilaksanakan selain di masjid seperti di rumah dan tempat yang lain yang dianggap cocok pada kondisi tertentu misalnya jika ada peserta Dirosa yang perlu dikunjungi. Hal tersebut juga menjadi kunjungan atau silaturrahim terhadap peserta yang mulai tidak hadir atau menurun semangat sehingga menambah kembali semangat peserta dan mengurangi kemalasan.

d. Melakukan Sosialisasi dan Perekrutan Pengajar Dirosa

LP3Q DPD Wahdah Islamiyah Makassar perlu lebih giat lagi dalam memperkenalkan Metode Dirosa agar semakin banyak masyarakat yang mengenal dan merasakan manfaatnya. Selain itu, dibutuhkan segera penambahan jumlah pengajar dengan melaksanakan perekrutan dan pelatihan bagi calon pengajar Dirosa mengingat saat ini jumlah permintaan peserta yang akan belajar Dirosa semakin bertambah.

\section{KESIMPULAN}

Dari pembahasan tersebut di atas, penulis menyimpulkan hal-hal sebagai berikut:

1. DPD Wahdah Islamiyah Makassar melaksanakan pembelajaran Al-Qur'an dengan menggunakan metode Dirosa berdasarkan bimbingan dan arahan dari LP3Q DPP Wahdah Islamiyah. Pembelajaran Al-Qur'an dengan menggunakan metode Dirosa dilaksanakan selama 20 kali pertemuan dengan jumlah peserta 10-25 orang per kelompok. Setiap pertemuan dilaksanakan 
selama 90 menit yang terdiri atas tiga tahap yaitu pembukaan, inti, dan penutup. Metode yang digunakan dalam pembelajaran adalah metode klasikal dan metode drill.

2. Kemampuan peserta sebelum mengikuti pembelajaran Al-Qur'an dengan menggunakan metode Dirosa terbagi atas tiga kategori yaitu kategori buta huruf yang tidak bisa sama sekali membaca Al-Qur'an, kategori terbata-bata, dan kategori lancar namun ada kesalahan dalam penyebutan makhraj dan kesalahan tajwid yang lainya. Secara umum peserta sudah mampu membaca Al-Qur'an setelah mengikuti pembelajaran Al-Qur'an dengan menggunakan metode Dirosa.

3. Kendala-kendala yang menghambat pembelajaran Al-Qur'an dengan menggunakan metode Dirosa yang dilaksanakan DPD Wahdah Islamiyah Makassar adalah jadwal pertemuan Dirosa yang sulit ditentukan, kurangnya kedisiplinan peserta, kurangnya waktu dalam mengulangi pelajaran, kendala tempat, dan kendala internal DPD Wahdah Islamiyah Makassar. Adapun solusi dalam mengatasi kendala-kendala tersebut adalah musyawarah antar peserta, memberi motivasi dan semangat kepada peserta didik, komunikasi dengan pengurus masjid, dan melakukan sosialisasi dan perekrutan pengajar Dirosa. 


\section{DAFTAR PUSTAKA}

Amal, Taufik Adnan. Rekonstruksi Sejarah al-Qur'an. Yogyakarta: Forum Kajian Budaya dan Agama (FKBA), 2001.

Komari dan Sunarsih, Panduan Pengelolaan dan Pengajaran Dirosa. Cet. III; Bogor: Yayasan Cita Mulia Mutiara, 2015.

Madyan dan Ahmad Shams. Peta Pembelajaran al-Qur'an. Yogyakarta: Pustaka Pelajar, 2008.

Ma'rifat, M. Hadi Sejarah al-Qur'an. Cet. II; Jakarta: Al Huda, 2007.

Al-Marāgi, Ahmad Musțafa. Tafsìr al-Marāgi. Semarang: CV Toha putra, 1993.

Muharram, Zulfisun. Belajar Mudah Membaca al-Qur'an dengan Metode Mandiri Cet. I; Jakarta: Ciputat Press, 2003.

Muhyiddin, "Buta Aksara Alquran Masih Tinggi", Republika.co.id. 09 January 2018. $\quad$ http://khazanah.republika.co.id/berita/dunia-islam/islamnusantara/18/01/09/p2a36z335-buta-aksara-alquran-masih-tinggi $(21$

Februari 2018).

Sa'dulloh, Metode Praktis Menghafal al-Qur'an Cet. I; Sumedang: Ponpes al-Hikamussalafi Sukamantri, 2005.

Safutra, Ilham. "54 Persen Muslim Indonesia Buta Aksara Al-Qur'an", $\begin{array}{llll}\text { Jawapos.com. } & 07 & \text { Januari }\end{array}$ https://www.jawapos.com/read/2016/06/07/32703/54-persen-muslimindonesia-buta-aksara-alquran (21 Februari 2018).

Al-Salih, Subhi Mabahis Fi Ulum al-Qur'an, Terj. Tim Pustaka Firdaus, Membahas Ilmu- Ilmu al-Quran Cet IX, Jakarta: Pustaka Firdaus, 2004.

Syarifuddin, Ahmad. Mendidik Anak Membaca, Menulis, dan Mencintai alQur'an. Bandung: PT. Remaja Rosdakarya, 2008

Tim Penyusun Kamus Pusat Bahasa. Kamus Besar Bahasa Indonesia. Cet. II; Jakarta: Balai Pustaka, 2002.

Wahdah Islamiyah. "Belajar Membaca Alquran Dari Nol Dengan Metode Dirosa", Situs Resmi Wahdah Islamiyah. http://wahdah.or.id/belajarmembaca-alquran-dari-nol-dengan-metode-dirosa/ (7 Maret 2018).

Yunus, Mahmud. Kamus Arab-Indonesia. Jakarta: Yayasan Penerjemah/Penafsir al-Qur'an, 1973. 